\title{
Suggestive techniques in music-performing training of future music art teachers: methodological aspect
}

\author{
Viktoriia Mishchanchuk
}

Kryvyi Rih State Pedagogical University, Department of Musicology, Instrumental and Choreographic Training, Kryvyi Rih, Ukraine

\begin{abstract}
The article deals with the use of suggestive techniques, which by influencing the conscious and subconscious sphere of future music arts teachers through the use of verbal and non-verbal, external and internal means of influence, will contribute to the disclosure of their inner potential, the development of creative thinking as well as the realization of their abilities into the practical activities. The author defines various spheres of the suggestive techniques use, in particular, in the process of future music teachers training and provides own interpretation of the concept of "suggestive technique in the music-performing training of future music teachers". In addition, the author offers methodological developments aimed at conducting creative music-performing activities - suggestopedic self-training of self-regulation skills along with suggestopedic method of forming the skills in artistic interpretation of a musical work, which is presented as a chain of suggestopedic classes, where each stage corresponds to a certain interpretation phase. Furthermore, it is noted that the developed methodological toolkit with the complex involvement of suggestive techniques with a number of methods, tools and approaches to art education along with the varied application of these methods in the process of students' professional training, methods of performing reliability formation and innovative methods, provides to carry out pedagogical influence on independence as well as performing activities effectively. Admittedly, the introduction of typical suggestopedic forms of classes (concert sessions, classes involving related arts, class performances, storytelling, play sessions) into the methodological toolbox brings additional aesthetic coloring into the interpretative processes, which, in combination with the globalization of the learning material, have led to the reconsidering of musical works artistic interpretation techniques on the whole.
\end{abstract}

\section{Introduction}

The processes of globalization and technologies integration in the educational field, and in the professional training of future music teachers in particular, are primarily aimed at finding and integrating traditional and innovative principles, methods, tools and forms of learning, developing and substantiating new approaches to the training of highly qualified, competitive, capable of self-discovery, self-development and self-realization of their abilities and opportunities in a creative activity specialists. Therefore, the use of suggestive techniques in the process of students' professional preparation, allowing exerting influence on the conscious and subconscious sphere of the personality through the use of verbal and non-verbal, external and internal means of influence, will contribute to the holistic perception of the world picture through a combination of both logical and imaginary mechanisms; the development of creative thinking, the discovery of the internal potential of a person as well as the achievement of the professional skill heights.

\section{Literature analysis}

It should be stressed that the analysis of scientific sources showed that in the field of philosophy and psychology, research on conscious and unconscious mechanisms of suggestion were conducted by A. Adler, M. Burno, J. Murphy, B. Porsnev, S. Rubinstein, P. Simonov, D. Uznadze, Z. Freud, K. Jung and others. Thus, S. Freud believed that the man's mind comprises two areas - the conscious and the unconscious. According to the researcher, the unconscious is deprived of any logic, is emotionally unstable, does not face external reality and lives to a greater extent in the past than in the present and acts on its own imaginary principles [1]. The suggestion issues were reflected in the fundamental writings of such prominent psychologists as T. Akhmedov, G. Goncharov, K. Kulikov, I. Monakhova, I. Schulz, etc. From the perspective of V. Kulikov, suggestion is a psychological influence, the exercise of which occurs through speech and non-verbal means and is characterized by reduced personality orientation [2]. The researcher G. Goncharov carried out a historical analysis of the origin of suggestion, examined the periods of suggestion, its varieties, teachings and their representatives [3]. In terms of our study, it was important to refer to the developments provided by the scientists R. A. Berk, S. Goncharov, G. Lozanov, S. Palchevsky, L. Tarasova, T. Chubukova, and others in

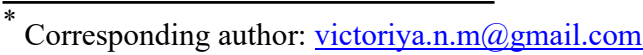


the field of suggestive techniques appliance in the educational process. The scientist G. Lozanov made a research into the problems of suggestology and developed a method that allows using suggestion to reveal the inner potential of the individual in the process of foreign languages learning [4]. Researcher S. Palchevsky modifies G. Lozanov's suggestopedic system and creates his own model of AECreS (Art, Emotionality, Creativity, Spirituality), the basis of which lay the psychological-physiological as well as didacticmethodological foundations. S. Palchevsky considers that the main goal of the pedagogical process is the development of the child's creative abilities, which should take place in specially created conditions of psychological comfort [5, 163-164]. The researcher R. Berk points out that the use of suggestive methods, means, forms of conducting classes (active and passive), developed by the eminent Bulgarian scientist G. Lozanov, plays a significant role in the students' learning process. Thus, the scientist is considering the use of musical art in the educational process with the purpose of aesthetization, creation of a corresponding emotional atmosphere in the classroom, improving efficiency along with rapid learning of the educational material. R. Berk draws attention to the issue of proper musical material selection in accordance with the tasks set by the teacher, students' characteristics and interests [6].

The problem of the use of suggestive means and suggestive techniques in the process of future music art teachers' training was reflected in the studies of E. Ekonomova, G. Erzhemsky, A. Kozyr, L. Masol, N. Morozova, V. Petrushina, O. Polyakova, T. Reisenkind, O. Rudnitskaya, V. Fedoryshyn and others. O. Polyakova's scientific work deals with the use of both verbal and non-verbal suggestion in the preparation of future music teachers, which are defined as four main streams - verbal, visual, tactile interrelation between the teacher and the student in music and performing classes, and - language of music. Owing to the lined out streams, the teacher affects the subconscious of students with the purpose of conveying and acquiring educational information [7].

Regarding the definition of "suggestive technique", L. Tarasova believes that this means allows carrying out the educational process in the state of wakefulness based on emotional suggestion [8, p. 216]. According to N. Morozova, the use of suggestion in the pedagogical process, namely in music lessons, contributes to a more effective implementation of any actions (learning the material, speed of memorization, etc.). The scientist believes that during the suggestion implementation, the suggerend experiences an altered state of consciousness (trance). This condition is characterized by a decrease in the function of the left hemisphere and the opening of access to the sphere of the unconscious, which leads to the disclosure of human creativity, awakening intuition as well as the development of its hidden resources of sensory systems. N. Morozova proposes that the future music art teachers would use the following suggestive methods in the lessons, namely: joining, choosing without choice, incorporation, psychological anchor or breaking the stereotype, which will increase the concentration and stability of attention and better assimilation of musical material, expanding a person's range of interests [9].

Such authors as A. Kozyr and V. Fedoryshyn emphasized the importance of using suggestion in future music professionals' training. The scientists claim that having a teacher an arsenal of suggestive methods and means, their use in the educational process will open up the students' internal potentials and will promote the suggestive abilities of future music teachers. Thus, these abilities will help the future specialist to create a favorable positive atmosphere of learning, solve complex creative tasks and exert emotional and volitional influence on the team in order to achieve the desired results [10]. Researcher N. Mukhorina notes that a modern teacher should have the latest techniques allowing him to influence children, but it is only possible if they have acquired certain suggestive skills. In her research, the scientist develops a set of techniques for suggestive skills formation, defines organizational and psychological and pedagogical conditions contributing to the formation of this phenomenon. N. Mukhorina notes that the use of suggestion by the teacher allows building subject-subject relations between the participants of the educational process, promotes activation of selfregulation and self-education processes with the younger generation, regulation and correction of their behavior as well as formation of their views and attitudes to the surrounding world [11]. T. Reisenkind's research indicates that the use of suggestive technique in the process of professional training of future music teachers allows them to influence their emotional-figurative sphere and thereby leads to an understanding of their own "I", stimulating the intuitive sphere, creating vivid interpretations of musical works [12]. While studying the use of suggestive techniques in music-performing training of future music teachers, we have come to the conclusion that the use of these techniques "... involves the organization of a psycho-dynamic complex process based on the mutual influences of partners at the conscious and subconscious levels in terms of psychological comfort; develops and forms certain musical and artistic representations of the personality, not inherent before, to create and realize original concepts of musical works in the performing process" $[13$, p. 66].

We believe that in order to achieve impregnable results in the process of students' music-performing training using suggestive techniques, it is important to develop the creativity of future music teachers, and thus provide for the formation of self-regulation skills as an effective tool for performing creative music and performance activities, interpretation activities, in particular.

The result of such a creative music-performing activity, in our opinion, is an ability to independently create an innovative, original product of a certain activity - a unique artistic image of a musical work that arises in the process of its interpretive processing. It is the complex involvement of suggestive techniques with a number of methods, tools and approaches to artistic 
education (artistic management, verbal, visual-anddemonstrational aids, etc.) and the varied application of these methods in the process of students' professional preparation that have effective pedagogical impact on the students' independence, originality of their musicperforming activities overall as well as their creative and interpretive activities as future music teachers in particular.

Correspondingly, considering the question of artistic teaching methods use in the process of future music teachers' music-performing training, in our study, we refer to the research by G. Padalka, who carried out their classification as follows: "by sources of transmission and nature of perception of artistic information; according to the nature of the artistic activity; in accordance with the nature of artistic tasks by stages of study; depending on the tasks of developing the students' personal artistic properties" [14, p. 178]. The first group of methods includes verbal, demonstrational-visual aids (visual) and artistic-creative (practical). The scientist emphasizes that the essential role in art education is given precisely to verbal methods (conversation, storytelling, explanation, discussion, current commentary, verbalization of works of art content), resulting in expanding the students' theoretical and methodical knowledge in the field of musical performance, directed at students' inner understanding of the essence of artistic images, obtaining valuable counselling on working on the image of a musical work, as well as on their activation to independence, expressing their own opinions and their own position on the understanding of the latter [14].

Obviously, in the course of music-performing training of future music teachers, it is advisable to use demonstrational-visual methods of artistic teaching as well. According to G. Padalka, this group is represented by the following methods: demonstrations of works of art and verbal explanations through artistic illustrations. The significance of the former method "... is to provide an example of the artistic result the student strives to, in providing a kind of standard for the study of educational material" [14, p. 183]. The latter method, the one of artistic illustration of verbal explanations, involves the demonstration of musical works with the indispensable presentation of certain theoretical positions regarding the given examples or reasoned own opinion and its presentation to the audience. An important feature of this method is the professional performance of a musical work. It should be noted that in the process of students' music-performing training, it is important to use the method of artistic management, which involves "multiple repetition of artistic actions in order to achieve perfection of their performance, fixation at the level of automatism" [14, p. 188], which will facilitate the formation of music-performing skills with the future specialists. The effectiveness of the method depends on the teacher's use of methodological and psychological recommendations.

The methodological support for future teachers of music art training with the use of suggestive techniques also involves the use of various creative tasks aimed at the development of musical interpretation skills, selfregulation of their psycho-emotional processes and states while working on a musical piece and the implementation of its interpretive concept in the musicperforming process. With regard to suggestive teaching methods, we propose the use of an autogenous training method developed by I. Schulz. This method involves the use of self-suggestion formulas in a state of rest for psychological self-regulation. The autogenous training helps future music teachers to overcome the negative phenomena (difficulties in learning a piece of music, presenting a composition to a listening audience, etc.) and reduce neuropsychiatric overload [15]. The implementation of this method and the achievement of the desired results depends on the formulated selfguidance formulas. According to E. Coue, they should be short, simple and not forced. Since the formula is addressed to our subconscious "I" and is perceived as an order for execution, it does not necessarily have to be true. You should also consider the positive component of the formula and try to avoid the "not" particle in its formulation. Also, the process of suggestion must take place without any willful efforts [16, p. 323].

Our study also dwells upon the integration of such suggestive methods that involve the use of verbal paths of information transmission based on a combination of linguistic, paralinguistic and extralinguistic means. Scientist L. Masol attributes these methods to suggestive methods of the linguistic group, which also includes paralinguistic and extralinguistic ones, and it is aimed at creating emotional situations of success, surprise or delight. The peculiarity of these methods is the use of intonation, figurative and timbre palette of voice, appropriate pauses and whispers to influence the students [17, p. 136]. In our opinion, it is also important to follow a certain rhythm and pace of speech, to use a dynamic scale to perceive, memorize, and reproduce educational information. Among the suggestion methods, we also propose to use the immersion method, which will allow future teachers of music art to dive deep into the world of musical images of a given musical piece, its history of origin, to learn about stylistic features of the composer, etc., as well as to create vivid concepts for music pieces and present them to a listening audience. In our study, we also support the use of aesthetic therapy techniques (involvement of various arts) to aesthetize the learning process, overcome nervous tension, and master the submitted material. In our opinion, the introduction of suggestopedic forms of classes (concert sessions, classes with the involvement of related arts, class performances, storytelling, play sessions), providing the involvement of our methods, contribute to the formation of original interpretations of music pieces.

\section{Methodological research results}

In the study, the strategy of formation of self-regulation skills in the process of music-performing training was designed to direct students through suggestive techniques to find an algorithm for self-organization and self-regulation of their own actions in the process of practical music-performing activity: during both ongoing individual and group activities as well as during the announcement of the results of music and performance 
training progress - at the credit-testing, exams, concert events in terms of higher education institutions.

The possession of self-regulation tools is a very important factor in the formation of music-performing readiness of future music teachers. After all, the developed skills of self-regulation determine the performer's reliability in revealing the results of the cooperative creative activity carried out by the teacher and the student.

Unfortunately, the pedagogical observations made during the exam sessions, modular control, concert events, etc., prove the absence of self-regulation skills in most students in practice not only in stressful situations when announcing results of their artistic and performing training, but even during ongoing individual and group activities. This is due, first of all, to the students' inability to psychologically adjust to the reproduction and presentation of the artistic image of the musical work to the audience and to overcome the excitement during the concert performance.

Scientists A. Kozyr, G. Padalka, D. Yunyk argue that there is a direct correlation between the formation of self-regulation skills in the process of creative musicperforming activity and reliability in communicating its results to the listener. According to D. Yunyk, “... the performing reliability of the artists of musical art is not an innate but acquired integral personal characteristics, which is manifested in the unmistakable, accurate performance of musical works in the regular and emotional conditions of the stage activity" [18, p. 125].

Based on the above statement of the researchers, it should be noted that for the effective performance of students' music-performing activities it is not enough to provide even careful, painstaking practice of learning end educational repertoire of the courses "Basic instrument", "Additional instrument", "Voice production", "Choral conducting", etc. After all, in the conditions of emotional stressful situations of the concert performance, the practice done often does not matter. As a rule, the implementation of the interpretative concept of creating an artistic image of a musical work, its operational and technical support, makes up no more than $60 \%$, and sometimes scores $20-30 \%$ of the performance of a musical work in the regular conditions of a classroom individual lesson.

Thus, these observations allow us to state the need for purposeful formation of self-regulation skills in the process of music-performing activities as a tool for immunity forming against the stressors. Therefore, the formation and development of these skills were carried out through specially developed methodological tools, which contain methods of performing reliability formation, innovative methods, as well as modern techniques of suggestive influence.

The Toolkit for Performance Reliability includes: - creative tasks for self-regulation of musical memory in its sensory, short- and long-term aspects, based on the methods of conscious selection of "valuable" musical information by activating arbitrary attention; methods of logical structuring of musical material; methods of selective performance of fragments of musical works; methods for ranking pieces of music according to the difficulty level of the memorizing them, etc.;

- creative tasks for self-correction of emotional and logical evaluation of intermediate and final results of music-performing activity;

- creative tasks for self-tuning for the implementation of the interpretative model of musical works;

- creative tasks of self-control during the implementation of artistic interpretation [13].

In order to form self-regulation skills in the process of music-performing training, we also created suggestopedic auto training of self-regulation skills, the basis of which was the suggestopedic method of autogenic modification. The application of this methodological support provided the creation of appropriate psychological and pedagogical conditions, namely:

- "students' psychological confidence as for the possibility of $100 \%$ reporting to the listener the results of artistic and performing training based on the development of self-regulation skills of their own actions;

- permanent provision of positive emotional support of the specified skills formation process;

- suggesting students' sensation/sense of their own rich intellectual and volitional potential" [19, p. 100].

During the training, the regulation of students' psychological state occurs first under the guidance of the teacher, and in the process of mastering the tasks of auto-training gradually transforms into self-regulation on the basis of enhancement of suggestion activity directed at itself.

The advantage of suggestopedic auto-training is that in the process of conducting it, the psychologicalpedagogical goals of the teacher-suggester and the student-suggerend are completely the same. The success of the self-suggestion process determines the level of self-regulation, and, which is very important for the effectiveness of the training itself, the student, in real time, is enabled to self-manage his or her own attention, memory and emotional manifestations.

In fact, an instrument of suggestopedic self-training for the formation of self-regulation skills in the process of music-performing training is lexical self-suggestion formulas [19, p. 100]. The use of these lexical formulas promotes concentration of attention, control of emotional state, actualization of intellectual activity, etc. So, we suggest to get acquainted with the suggestopedic selftraining of self-regulation skills in the process of musicperforming training on the basis of autogenic modification:

1. Identification of problematic situations in terms of self-regulation and specification of a positive set of achievements.

Task 1.1. Make a list of psychological and pedagogical problematic situations on the separate yellow cards that arise in the course of ongoing musicperforming activities during the individual lessons of the "Basic Instrument", “Additional Instrument", "Orchestra Class", etc., and during the exam-concert performances. 
Task 1.2. Rank the cards with the problematic situations recorded on them according to your personal importance value of solving them.

Task 1.3. In accordance with each of the ranked problematic situation, write a description of your own psychological and physiological state on the red cards, preventing the full realization of the artistic image of the musical work creation, its creative interpretation, the operational and technical side of the performance. Describe your own condition according to the emotional, intellectual and physiological-sensory components. (For example: "Before performing a musical element that contains a double note invoice, there is a timidity and tension, accompanied by the thought "Still does not work" and a feeling of "stiffness in hands").

Task 1.4. On green cards, use a lexical selfsuggestion formula to create a comprehensive positive description of psychological and physiological states that is completely opposite to that described on the red cards. (For example: "Before performing a musical element that contains a double-note invoice, there is a boldness and looseness, accompanied by the thought" I am sure I will play brilliantly "and a sense of "flexibility and ease of movement of hands"

The lexical self-suggestion formulas contained in comprehensive positive green card descriptions are to meet the following requirements:

1) punctuality, conciseness, capacity that promotes better perception and engaging in consciousness (short lexical formula: "I'm calm" works better than "I'm always calm when performing double notes";

2) affirmative positivity (the lexical self-suggestion formula should not contain any objection that may exacerbate the problem; for example, the lexical formula: "I'm not afraid to forget the text during a speech" can reinforce the fear; the lexical formula "I remember everything" works better);

3 ) individual orientation (the lexical self-suggestion formula works only at the personal level; if a certain key phrase helped solve the problem earlier, it can be used for autogenic modification; for example, if the word "Basta!" helped once overcome the fear of stage, then it can be engaged during the process) [13].

2. Autogenic modification: self-suggestion of a positive set of self-regulation skills.

Task 2.1. Compiling all cards, make a table containing 3 columns: yellow, describing the problematic situations, red, describing the negative set of feelings, and green, describing the positive complex containing lexical self-suggestion formulas.

Task 2.2. In calm, focused state, work with the table as follows, starting with the first, easiest task:

1) look at the yellow card with the record of the problem situation;

2) symbolically remove a red card from the table describing the negative set of feelings;

3) being concentrated and focused, repeat the description of the positive set of sensations containing lexical self-suggestion formulas;

4) after completing the first task, move on to the next one.
3. Autogenic modification in the mode of relaxopedic training: self-suggestion of a positive set of selfregulation skills in the state of relaxation.

Task 3.1. In case of major difficulties, such as the total inability to recollect sheet music during public performance, work with an autogenic modification using a card table in Relaxopedic Training under the teachersuggester's guidance. The systematic combination of autogenic modification with the state of relaxation provides self-regulation in order to resolve the problematic situation in the process of music-performing training.

To measure the formation of self-regulation skills of future music teachers in the process of music-performing activity, we have used the modified methodology of N. Kuzmina and V. Ginetsinsky "Diagnostics of skill mastery of self-regulation methods in the process of music-performing activity as well as during concert performance" [20]. The carried out diagnosing of future music teachers allowed us to state that the students acquired the ability to self-regulate in the process of professional training, which facilitated the concentration of their attention on the creation and presentation of the integral emotional-figurative content of the artistic work, performing technical and artistic tasks, regulating inner psycho-emotional processes in order to realize the interpretative concept of musical composition in the performing process.

We believe that in the process of music-performing training of future music teachers, it is important to develop the ability to create an independent and original interpretation of musical works, which fully attests to the degree of development of students' creative and thinking qualities.

Thereby, O. Scholokova insists on the necessity of overcoming reproductive and imitative tendencies in the interpretation of musical works. The researcher notes that "... every interpretation of a work of art begins with one's own, individual interpretation, i.e., proceeds from perception" [21, p. 75].

At the same time, one cannot deny the leading role of teachers' guidance in such subjects as "Basic Musical Instrument", "Orchestral Class", "Choral Class", "Voice Performance", musical-theoretical disciplines on the formation of musical interpretation skills in the process of music-performing training. We have specially created a suggestopedic technique of forming the skills of artistic interpretation of musical works. The goal of this methodology is to bridge the gap between the reproductive and independent ways of performing artistic interpretation of musical works in the context of the synthesis of rational and intuitive in the process of students' music-performing training.

The goal has been achieved by introducing characteristic suggestopedic forms into the methodological toolkit, namely: concert sessions, classes involving related arts, class performances, storytelling, play sessions and more. These suggestopedic forms have introduced additional aesthetic coloring into the interpretative processes, which in combination with the globalization of teaching material have led to the 
reconsidering of musical works artistic interpretation techniques on the whole.

The methodology is based on the basic principles of suggestopedia developed by G. Lozanov, namely:

- "joyful and spontaneous concentrative calmness;

- dynamic, structured and hierarchical globality - the part in the global and the global in the part; the global as a part and the part as a global; and

- desuggestive set-up with the aim of the spontaneous freeing of the reserve capacities of the mind and brain" $[4$, p. 66].

The essence of the methodology lies in the globalization of the educational material regarding the basic laws of the interpretation process, which allows to begin to elaborate a piece of music as a whole, to summarize its figurative and artistic content, generalizing its nature, without focusing on the first stage of the interpretation process in detail. However, in the further interpretative elaboration, the individual details should be considered as certain elements of one musical integrity.

The specific characteristics of the methodology include the following:

1) "embeddedness" in the above suggestopedic forms of teaching methodical tools of artistic teaching: verbal methods (conversation, current commentary, verbalization of the content of musical works), demonstration methods (demonstration of musical works, artistic illustration of verbal explanations, etc.); methods of artistic management, varied development of artistic material, creation of artistic images; musicpedagogical discussions, art debate, etc.;

2) the availability of aesthetic means of the interpretation process or artistic means of art, which are the natural component of creating artistic interpretation in the context of a system-holistic approach: the means of music, choreography, painting, fine and applied arts, photography, cinema, etc.;

3) the orientation of methodological support for the creative interpretation skills formation on the creativity of the interpretation process in the context of originality and independence:

- the role of the teacher is presented solely in providing the most favorable conditions for the students' interpretive activity;

- the interpretative processing itself is carried out by students independently.

Thus, the suggestopedic method of forming the skills in artistic interpretation of a musical work, is presented as a chain of suggestopedic classes, where each stage corresponds to a certain interpretation phase of the process. This method is assigned for such disciplines as "Orchestral Class", "Choral Class", during which there are constantly occurring problematic situations in the implementation of students' interpretive skills. At the same time, the methodology can be adapted and applied during individual lessons in "Basic Instrument", "Additional Instrument", "Concertmaster Class", etc.

Stage I. Music study context. Content: comprehensive and substantiate introduction of students to the global historical and theoretical information about the historical era in which the author of a musical work under interpretation lived and worked, about the creativity of the designated author, corresponding artistic direction, his or her artistic and stylistic features. The suggestopedic form - a concert session. The lesson lasts for an academic hour, which is very convenient for both individual and group classes in the current conditions of music-performing training of future music teachers.

The concert session requires the careful preparation of the teaching assistant. During the preliminary preparation for the concert session, the teacher selects an auxiliary piece of music or a medley of several works that belong to the same era, the same artistic direction as the main piece of music planned for interpretation. It is also possible to use a piece of music as an ancillary by the same author as the main work. Suggestopedic requirements for the selection of ancillary work:

- the work of music should be calm, contemplative;

- the piece of music is to contain artistic and stylistic features characteristic of the artistic direction in which the main composition is created;

- the duration of the ancillary musical work should exactly coincide with the duration of the sound of the educational material planned for teaching;

- the performance of the ancillary piece must be perfect.

During the preparation for the concert session, the teacher-suggester will listen to the ancillary piece of music several times in order to determine figurative changes of mood, nuance, tempo, dynamics, etc. After that, he distributes the educational material on historical and theoretical information about the era of creation and author of the main musical work, the corresponding artistic direction, characteristic style features, etc. in accordance with the characteristics of the sound of the ancillary musical work. The teacher-suggester should train the nuances of the sound of the voice in the process of teaching the teaching material in accordance with the nuances of the work. These are the factors to determine the quality of learning information by the students.

Methodological requirements for conducting a concert session:

1) the behavior of the teacher-suggester at the beginning of the concert session corresponds to the beginning of the concert: solemn and restrained;

2) teaching of learning material begins after the sound of a musical introduction or after the presentation of the first musical theme of the work with full breath: the intonation of the text is sublime, but depending on the nature of the sound of the ancillary music work;

3 ) the phrases pronounced by the teacher-suggester must coincide with the musical phrases; any change in timbre, strength, dynamics of voice is caused by changes in music: joyful, confident intonations correspond to the major system; melancholic, lyrical - minor;

4) the beginning of the speech falls on the first strong part of the musical phrase, and the end - on the last weak; if there is a corresponding malfunction in the speech, it is necessary to wait for the end of the musical phrase and quietly continue the production with a strong fate of the next musical phrase;

5) the rate of speech depends on the agogics of the ancillary musical work [13]. 
Thus, a properly conducted concert session allows students not only joyfully and without strain to absorb the educational information of the musical-theoretical content necessary for a competent, well-grounded interpretative process at the global level, but also empirically, by means of the perception of the ancillary work, to confirm educational information on the embodiment of the composer's creative intent in the characteristic stylistic features of the musical language of a particular era.

After the concert session, the teacher invites students to work independently for a week (before the second session) to find and study music-theoretical, musicalhistorical literature in the context of continuing the global acquaintance with the era and artistic direction in which the main musical composition was created.

Stage II. Music-operating context. Content: on the basis of demonstration and comparison of different performances of the main work be able to formulate a detailed definition of its character, as well as an analysis of the means of musical expression (musical form, melody, harmony, metro-rhythm, texture, dynamics, strokes, etc.) in creating a defined character. Suggestopedic form - lessons with the involvement of related arts. Duration - an academic hour.

Engaging with related arts, as well as a concert session, requires careful teacher's preparation. Classes engaging with related arts are conducted using multimedia tools - interactive whiteboards, monitors, tablets - depending on the equipment at the audience's disposal.

The teaching material is assembled by the teacher as follows: students are offered several different options of performing the main work under interpretation. Each version of the performance is accompanied by a display of works of painting, sculpture, architecture, etc. of the relevant cultural era. The aforementioned show is purely illustrative in nature and does not need to be focused on. The suggestopedic meaning of the illustrative display is the aesthetic coloring of the process of musical perception of the main work, the understanding of its figurative and artistic content in the context of the globalized perception of the corresponding historical and musical style. The duration of this part of the class is 30 minutes, during which students are to listen to at least 3 variants of the performance of the main work, in order to prevent the creation of stereotypes in further interpretive processing.

During the next 15 minutes, students should spend on a thorough, generalized definition of the character, figurative content, genre, and form of a piece of music that must be done on a hearing basis in writing.

The homework that students receive after engaging in related arts is to independently write a musicaltheoretical analysis of the main work in accordance with the requirements of the course "Analysis of Music Works". The use of sheet music is required for homework. Means of musical expression are analyzed solely in the context of a generalized, detailed definition of the nature and artistic content of a piece of music on the basis of a globalized understanding of the genre-style features of the musical direction in which the work was written.

Stage III. Analytical and pedagogical context. Content: assessing the level of musical and performance complexity of the work, as well as revealing its musical and pedagogical potential. Suggestopedic form -an interactive game lesson.

The lesson lasts 45 minutes. Applying interactive games such as "Student as a leader of an orchestral collective", "Artistic debate in the style of television talk shows", "Scientific and practical conference on artistic interpretation of musical works", "I am the moderator of the round table", etc., students are to analyze a number of music-performing tasks concerning the interpretive creation of an artistic image of a musical work, to specify the musical-performing means of maintaining the integrity of the form, to detect the point of the "Golden Cross", to reproduce the musical style, inherent to a particular musical direction, to plan nuances and dynamics, etc. in the context of the author's design. They are also to determine the pedagogical potential of a musical work in order to form students' interpretive and performing skills on the basis of the collective formulation of conclusions.

After the interactive play, students are given a written homework assignment, a creative assignment "Annotation-interpretation of a musical work", in which the author's two recommendations for the interpretation of the musical work are added to the two previously completed assignments. The completion of the specified creative task can serve as a basis for the preparation of module control testing, credit or examination in the subjects of "Orchestral class" or "Choral class". It should be noted that the use of this method provides practical preparation of students for the exam in the field of creating an annotation of a polyphonic piece of music, which is a mandatory requirement for its compilation.

As the study shows, we tested the method of formation of artistic interpretation skills of a musical work by the method of I. Grinchuk and O. Burska "Diagnostics of Musical and Performing Thinking: Instrumentation Kit" [22, p. 202-221], which showed the positive dynamics of raising the level of formation of certain music art skills in the process of musicperforming training of future specialists.

\section{Conclusions}

Thus, the analysis of scientific sources on the problem of the use of suggestive techniques in music-performing training of future music teachers allowed us to provide our own definition of the concept and to create the author's methods of music-performing training of future music professionals using suggestive techniques in the educational process, namely: suggestopedic auto-training for formation of self-regulation skills in the process of music-performing training, suggestopedic method of formation of skills of musical work artistic interpretation. The developed methodological toolkit of techniques is based on the combination of forms, methods and means of suggestive influence with the forms, methods and means of artistic teaching. Performing creative tasks to ensure performing 
reliability, creating appropriate psychological and pedagogical conditions and lexical self-suggestion formulas during self-suggestive auto-training for selfregulation skills formation has contributed to the development of creative and intellectual capabilities of individuals, improving the performance of musical and performing activities by updating and self-correcting the inner state of music specialists. Moreover, the introduction of regular suggestopedic forms of classes (concert sessions, classes involving related arts, class performances, storytelling, play sessions) into the methodological toolbox of the methods of musical work artistic interpretation skill formation, the availability of bringing aesthetic coloring into the process of interpretation and teaching classes conducting contribute to students' reserve opportunities revelation aimed at increasing the volume of learning material, deep immersion into the imaginary world of performing works, creating and implementing original and unique interpretations of musical works in the performing process.

Thus, the proposed author's methodological developments in future music teachers' musicperforming training using suggestive techniques in the educational process opens new perspectives of students' personal and professional progress and contributes to their reaching of professional skill pinnacles.

\section{References}

1. S. Freud, The ego and the id, ed. by J. Strachey (W.W. Norton, New York, 1962)

2. V.N. Kulikov, Psihologiya vnusheniya (Psychology of Suggestion). (IvGU, Ivanovo, 1978)

3. G.A. Goncharov, Suggestiya: teoriya i praktika (Suggestion: theory and practice). (Prosveshenie, Moskva, 2008)

4. G. Lozanov, Suggestopaedia-desuggestive teaching. Communicative method on the level of the hidden reserves of the human mind, Summary of Lectures 1995-2005 Vienna (2005), http://www2.vobs.at/ludescher/pdf\%20files/suggest opaedia\%20-\%20book.pdf. Accessed 5 Mar 2020

5. S.S. Palchevskyi, Suhestopedahohika: novitni osvitni tekhnolohii (Suggestion education: new technology). (Kondor, Kyiv, 2005)

6. R.A. Berk, Use of Technology and Music to Improve Learning (2008), https://images.pearsonassessments.com/images/NES Publications/2008 12Berk 13012 1.pdf. Accessed $\overline{5}$ Mar 2020

7. E.S. Polyakova, Psihologicheskie osnovy muzykalno-pedagogicheskoj deyatelnosti (Psychological foundations of musical pedagogical activity), 2nd edn. (BGPU, Minsk, 2005)

8. O.M. Piekhota (ed.), Osvitni tekhnolohii (Educational technologies). (A.S.K., Kyiv, 2001)

9. N.V. Morozova, Vestnik kafedry YUNESKO "Muzykalnoe iskusstvo i obrazovanie na protyazhenii zhizni” 4, 57-67 (2016)
10. A.V. Kozyr, V.I. Fedoryshyn, Vstup do akmeolohii mystetskoi osvity (Introduction to artistic education acmeology). (Vyd-vo NPU imeni M. P. Draghomanova, Kyiv, 2012)

11. N.B. Muhorina, Dissertation, Kolomna State Pedagogical Institute, 2003

12. T.Y. Reizenkind, Dydaktychni osnovy profesiinoi pidhotovky vchytelia muzyky $v$ peduniversyteti (Didactic foundations of vocational training of music teacher at a university). (Vydavnychyi dim, Kryvyi Rih, 2006)

13. V.M. Mishchanchuk, Dissertation, National Pedagogical Dragomanov University, 2015

14. H.M. Padalka, Pedahohika mystetstva (Teoriia $i$ metodyka vykladannia mystetskykh dystsyplin) (Art Pedagogy (Theory and methodology of teaching artistic disciplines)). (Osvita Ukrainy, Kyiv, 2008)

15. I. Schultz, Übungsheft für das autogene Training: Konzentrative Selbstentspannung (Georg Thieme Verlag, Stuttgart-New York, 1983)

16. T. Ahmedov, Prakticheskaya psihoterapiya: vnushenie, gipnoz, meditaciya (Practical psychotherapy: suggestion, hypnosis, meditation) (AST, Torsing, Moskva, Harkov, 2005)

17. L.M. Masol, Khudozhno-pedahohichni tekhnolohii v osnovnii shkoli: yednist navchannia $i$ vykhovannia (Artistic and pedagogical technologies in primary school: unity of education and upbringing) (Drukarnia Madryd, Kharkiv, 2015)

18. D. Yunyk, Teoriia ta metodyka mystetskoi osvity. Naukova shkola H. M. Padalky (Theory and methodology of art education G. M. Padalki Scientific School), 2nd edn. (NPU imeni M. P. Draghomanova, Kyiv, 2011), pp. 121-150

19. V.M. Mishchanchuk, Academic notes. Series: Pedagogical Sciences 170, 97-101 (2018)

20. A.A. Karelyn (ed.), Psihologicheskie testyi (Psychological tests), vol. 2 (VLADOS, Moskva, 2003)

21. O.P. Shcholokova, Osnovy profesiinoi khudozhnoestetychnoi pidhotovky maibutnoho vchytelia (Fundamentals of professional future aesthetic preparation of a future teacher). (Vipol, Kyiv, 1996)

22. I. Hrinchuk, O. Burska, Problemy muzychnoho myslennia: teoriia i metodyka rozvytku. Dialektyka muzychnoho lohosu ta eidosu (Problems of Musical Thinking: Theory and Methods of Development. Dialectics of music logos and eidos). (Pidruchnyky i posibnyky, Ternopil, 2008) 